\title{
INHIBITION OF ADRENOCORTICAL ACTIVITY BY DEXAMETHASONE IN NEWBORN PIGLETS
}

\section{DVORÁK}

Veterinary Research Institute, 62132 Brno

Received August 23, 1985

\begin{abstract}
D v o a k.: Inhibition of Adrenocortical Activitu bu Dexamethasone in Newborn Piglets. Acta Vet. Brno, 55,1986:155-161.

Dexamtehasone was given orally to half of the piglets of two litters in one $0.25 \mathrm{mg}$ dose within one hour of birth and to half of the piglets of other two litters in two $0.25 \mathrm{mg}$ doses on the 3rd day after birth. The remaining animals in each litter served as controls. All the piglets were exsanguinated 12 hours after treatment. The concentration of 17-hydroxycort1costerolds (17-0HCS) in the plasma of newborn and three-day-old experimental piglets was reduced 64 and 36 per cent, respectively, as against the controls. The capacity of adrenal slices to produce 17-0HCS in vitro on stimulation with corticotrophin was suppressed in the two groups by 20 and 16 per cent. The treatment with dexamethasone also affected ascorbic acid concentration in the adrenal, produced a non-8ignificant increase in blood glucose, reduced ascorbic acid concentration in the blood plasma and liver and had no effect on adrenal mass and on the circulating eosinophile granulocyte level. The demonstration of negative feedback and the decrease of endogenous corticosteroids confirmed functional maturity of the pituitary-adrenal system in newborn piglets. The foetal-maternal relations are analysed from the viewpoint of comparative physiology and the mechanisms controlling corticosteroid level in piglets during the perinatal period are discussed.
\end{abstract}

Corticosteroids, ACTH, feedback, development, pig.

Investigations of the pathogenesis of splayleg of newborn pigs have shown that the degenerative changes of skeletal muscle are morphologically similar to those seen in corticoaterold myopathy ( $\mathrm{z}$ e $\mathrm{l} \mathrm{e}$ á and $\mathrm{J} I \mathrm{r} \mathrm{m} \mathrm{a} \mathrm{n}$ o vá 1979). A hypothesis suggested the involvement of a hormonal imbalance, an increased production of corticosteroids in foetuses as a result of stressors to which sows are exposed in the last third of pregnancy ( $T u c k$ et al, 1980). The recent prevalence of this congenital disease has drawn attention to the question of physiological preconditions for the development of foetal hyperadrenocortism, the clinical form of which has not been decsribed (C 1 e ve 1 a n d 1970).

Some Indication of foetal hyperadrenocortism can be seen in the observation that the concentration of 17-hydroxycort1costerolds (17-0HCS) in newborn pigs was several times higher on the first day after birth than in older resting pigs (D $v$ o a $k$ 1967). Although few data are avallable on the endocrine changes in pigs during their foetal development, the observations on adrenal sterolds suggest a physiological rise of adrenocortical function of foetal pigs during the last 15 to 20 days of gestation (D v o t́á $k$ 1972, 1973a; F è r e 1975).

The level of corticosteroids in the blood plasma of sows at farrowing time 18 substantially lower than in newborn piglets ( $F$ $r$ e 1975; $B$ e $n$ e r and $G \ddot{u} r t$ e $r$ 1977). In man the reverse 18 the case: the level of cortisol in the umbllical plasma 18 only 20 to 30 per cent of that of the mothers who have their cortisol concentration several times increased at parturition ( $\mathrm{K}$ a $\mathrm{P} 1 \mathrm{l}$, et al. 1972). Examination of foetal monkeys a few days before birth showed that 58 pcs cent of their cortisol was of maternal origin ( $\quad 1$ t $t$ I $g$ e $r$ 1974). However, there 18 no evidence of transplacental transfer of maternal adrenocorticotrophic hormone (ACTH) in

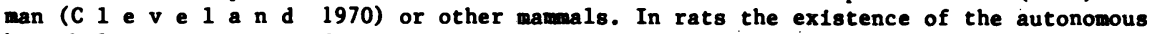
hypothalamus-pituitary-adrenocortical axis was described in the last days of foetal development ( $\mathrm{C}$ r b 1 e $r$ and $R$ of $f$ 1 1978). Nevertheless, lack or excess of 


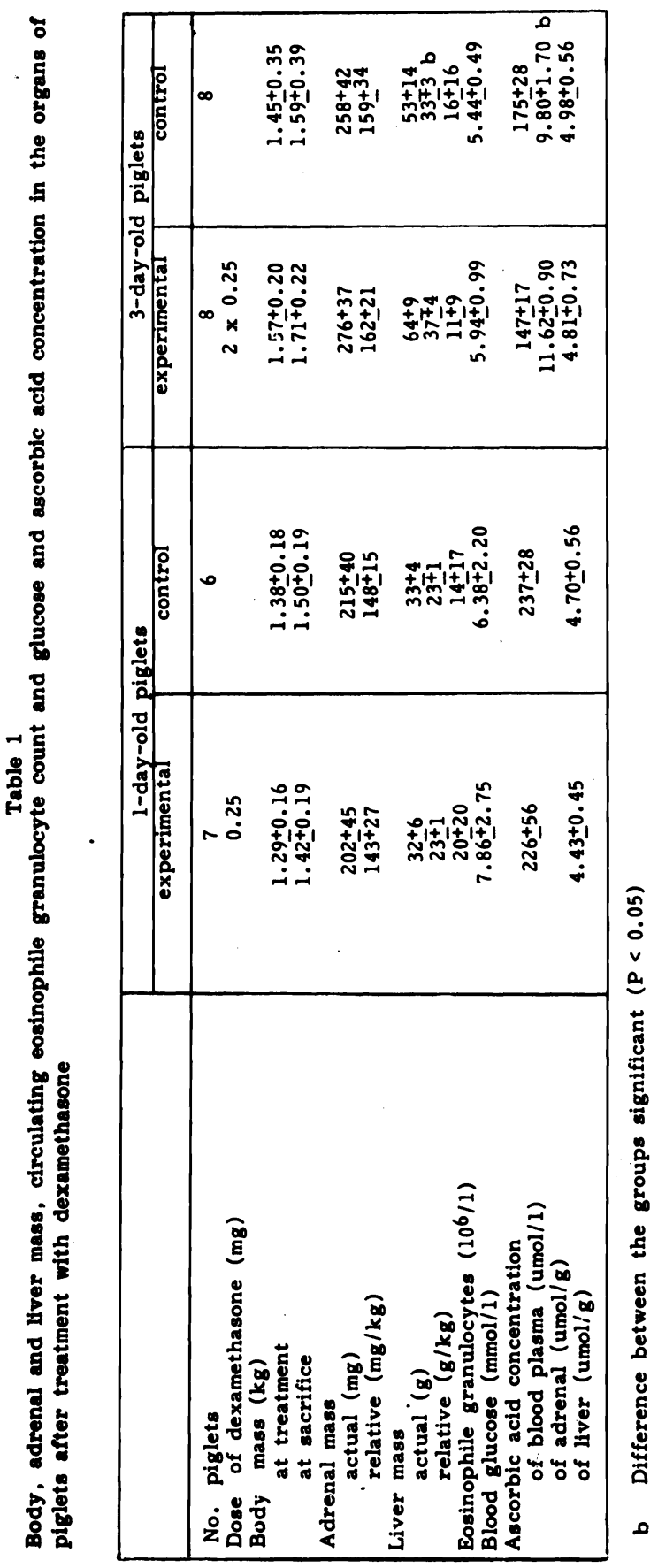


maternal cort1costerolds in rats in late gestation affects the secretion of ACTH by the foetal pituitary ( $D$ ' A $\mathrm{n}$ e 1 o et al. 1973).

The perinatal development of adrenocortical function including the foetal, placental and maternal relations varies substantially from species to species. In pigs the main role In the rise of foetal adrenal mass was attributed to ACTH secreted by the foetal pituitary (D $v \circ$ á $k$ 1973a). If one adnits that cort1costerolds pass through the placenta of the sow at an enhanced rate when the animal is in a state of stress, then they should exert a suppressive effect on the foetal pituitary. Inhibition of ACTh secretion during the perinatal period would not occur if the negative feedback mechanism were absent.

The negative feedback of corticosterolds and ACTH lies in that an excess of corticosteroids inhibits the secretion of superior ACTH. In the cortisol servomechanism a decrease in free cortisol, on the other hand, results in increased secretion of ACTH whereby cortisol level 18 maintained within a relatively narrow range unless increased secretion of adrenocortical hormones 18 included under stressful conditions by hypothalamic ACTH-releasing factor.As far as $18 \mathrm{known}$, all sterolds with corticold activity are more or 1 ess able to Inhibit ACTH secretion and thus to cause a reduction in corticosteroid secretion through feedback action. Cort1sol is the major inhibitor in those mamals in which 1t is the main glucocorticold (G a $\mathrm{n} t$ et al. 1965). A remarkably high potency in this respect 18 exhibited by synthetic dexamethasone which 18 used in human medicine in variously modified tests for exanination of the syndromes of adrenocortical hyperfunction. In p1gs of $20 \mathrm{~kg}$ in body ass pretreatment with dexamethasone at 4 or $8 \mathrm{mg}$ cancels the pituitary and adrenocortical response to some stimuli ( $\mathrm{o} n$ a $1 \mathrm{~d}$ et al. 1968; C o o k et al. 1974).

The object of the present study was to confirm or to exclude the possibility of the endogeneous production of corticosterolds being suppressed after their exogeneous supply.

\section{Materials and Methods}

Large White piglets of 4 litters were employed. Half of the animals in each litter were left untreated to serve as controls. Experimental piglets of two litters ( 7 animals) were treated with Dexamethazon SPOFA (9alpha-fluoro-16alpha-nethylprednisolone) orally In a dose of $0.25 \mathrm{mg}$ within one hour of birth when all piglets were weighed at $7 \mathrm{p} . \mathrm{m}$. Experimental piglets of the other two litters (8 animals) were treated with two oral doses of the same drug on the 3 rd day after birth at 7 a.m. and 7 p.a. All the experimental and control animals were exsanguinated by decapitation on the following day at 7 a.m. The characteristics of the groups are given in Table 1.

Deterainations were ade of actual and relative adrenal and liver ass, eosinophile granulocyte count and glucose concentration in the blood, 17-hydroxycorticosterold (17-0HCS) concentration in the plasma and ascorbic ac1d concentration in the plasma, adrenal and liver. The adrenals were also used for determination of the production of 17-0ACS by adrenal silces in vitro on incubation with ACTH. The wethods have been described in previous publications (D $v$ o $k$ 1972, 1973b, 1974). The results are tabulated as arfthmetic means \pm standard deviations and shown graphically as means \pm standard errors. of the means. The significance of the differences of the weans was assessed by Student's t-test.

\section{Results}

The administration of dexamethasone to newborn and three-day-old piglets had no distinct effect on either their body mass or eosinophile granulocyte count or actual and relative adrenal mass as determined at 12 and 24 hours of the experiment, respectively. Blood glucose concentration was non-significantly higher and ascorbic acid concentration in the plasma and liver were non-significantly lower in the experimental animals than in the controls (Table 1). The animals treated on the third day after birth had a significantly ( $P<0.05$ ) higher ascorbic acid concentration in the adrenal and a higher relative liver mass as against the controls.

The most prominent changes occurred in the direct criteria of adrenocortical activity. The administration of dexamethasone reduced significantly $(P<0.01)$ the concentration of 17-OHCS in the blood plasma and distinctly, though not significantly, the production of 17-OHCS by adrenal slices in vitro on incubation with ACTH (Fig. 1). It is noteworthy that the suppressive effect made itself felt more in newborn piglets: their plasma 17-OHCS level was reduced 64 per cent, whereas that of three-day-old piglets only 36 per cent as against the controls. Similarly, the production of 17-OHCS by adrenal tissue in vitro was depressed 20 per cent in newborn piglets and 16 per cent in three-day-old animals as against the controls. 


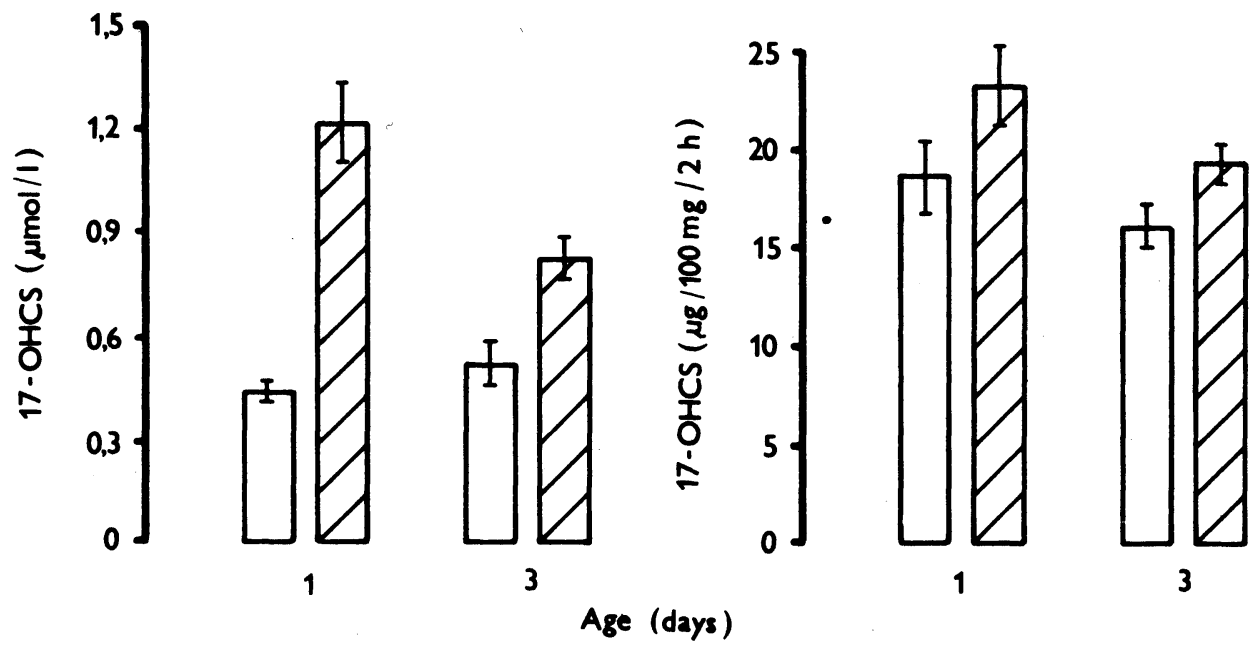

F18. 1

Concentration of 17-hydroxycorticosteroids (17-0HCS) in the blood plasma and their production in vitro by adrenal slices after stimulation with ACTH in dexamethasone-treated (open bars) and control (hatched bars) piglets aged 1 and 3 days.

\section{Discussion}

The concentration of 17-OHCS in the plasma of control piglets was in keeping with the high values recorded in the first days after birth ( $D \vee 0$ with its progressive decrease. In the present case it was 33 per cent lower at 3 days of age than the first day. Concurrently, a somewhat less pronounced decrease was recorded in the production of $17-\mathrm{OHCS}$ by adrenal tissue in vitro. The lower values in the experimental piglets than in the controls show quite convincingly that dexamethasone reduced the production of adrenocortical hormones and their release into the blood stream. Further evidence of it can be seen in the ascorbic acid level which decreases in the adrenal and rises in the blood and possibly also in the liver when enhanced adrenocortical function is induced with exogenous ACTH or by stress on starvation ( $\mathrm{D} \vee \circ \mathrm{a} k$ 1973b, 1974). The dose of dexamethasone was apparently not too large and did not act long, for one-day-old piglets did not develop enlargement of the liver which was found in three-day-old piglets treated with two doses or after stimulation of the adrenal cortex for two days ( $D \vee \circ \dot{r} a k$ 1974). There was only a slight difference between the experimental and control piglets in the count of circulating eosinophile granulocytes. This, together with the decreased level of plasma 17-OHCS in the experimental animals, suggests that dexamethasone which is quick to induce eosinopoenia (B l e n $\mathrm{k}$ i s o p p and B l e n $\mathrm{k}$ n o p p 1967) ceased practically to act 12 hours after administration. However, its waning effect was still perceptible, giving rise to a mild hyperglycaemia. The most important observation is the finding that the dose of synthetic glucocorticoid employed had a suppressive effect on the mechanisms controlling cortisol secretion.

The high values of 17-OHCS in the blood of newborn piglets indicate a certain degree of hypercortisolism as compared with the older animals. A similar state is found in human medicine in patients with Cushing's disease where, however, hypercorticalism is manifested clinically, the hyperfunction of the cortex being responsible for impairment of homeostasis. In piglets this state is, no doubt, physiological and corticosteroid hypersecretion can be regarded as an adaptive process. A high degree of maturity of the 
hypothalamus - pituitary-adrenocortical axis in response to stressors has been demonstrated (D $v \circ$ a $\mathrm{k}$ 1973b). Considering their response to suppressive action of dexamethasone, the piglets aged one and three days can be regarded as qualitatively mature also from the viewpoint of the feedback control of the hypothalamus-pituitary-adrenocortical system. The existence of negative feedback was demonstrated experimentally also in neonatal infants ( $\mathrm{O}$ u $\mathrm{n}$ o et al. 1972). However, their plasma corticosteroid level differs from that found in piglets in that it decreases within 1 to 2 days of birth to the level found in older children. This is obviously the result of suppressive action of cortisol that is transferred from maternal to foetal blood during labour ( $T$ e $r$ v i l l 1 ä et al. 1969) and reduces cortical secretion in the newborn. There is also evidence in rats that the feedback mechanism is functional during foetal and early postnatal life (S c h a p i r o 1965; K l e p a $\mathrm{c}$ and $M$ i l k o vi c 1979) so that perhaps even endogenous hormones may inhibit stress response by previous action on the neonatal pituitary. Large doses of dexamethasone may suppress the increase in corticosteroid level in a state of stress ( $D$ o $n$ a 1 d et al. 1968; S i $r$ t and $G$ i b s 1969), but dexamethasone does not affect adrenal response to exogenous ACTH (H a $r$ et al. 1969). The sensitivity to ACTH after such treatment may be even enhanced (B r a $\mathrm{n} s$ o m e 1968). In the present study this was apparently not the case in the production activity of adrenal slices in vitro.

In the light of the contemporary knowledge and of the observations reported here it seems reasonable to explain the state of adrenocortical activity in neonatal piglets as follows: High 17-OHCS levels found in the blood plasma of piglets in the days of postnatal life are not dependent on the dam, but they are the product of endogenous corticosteroid biosynthesis. Adrenocortical hyperfunction is being prepared in about the last 20 days of intra-uterine development and apparently plays a role in the initiation of parturition. It is conditioned by hyperplasia of the cortex and by a high degree of secretion of foetal ACTH. Feedback mechanisms of the hypothalamus-pituitary-adrenocortical system are functional and appear particularv sensitive in newborn piglets. Treatment with dexamethasone can suppress adrenocortical secretion. The high basal level of endogenous cortisol in the blood apparently suppresses ACTH release more moderately so that except in the first days after birth the subsequent decrease in resting 17-OHCS concentration of the blood is relatively slow. This situation is no obstacle to the response of the hypothalamus-pituitary-adrenocortical system to experimental stressors. When the life of a neonatal pig is endangered in the first days after birth, the high basal plasma 17-OHCS levels may be further increased considerably ( $\mathrm{v} \circ \mathrm{f}$ a $\mathbf{k}$ 1973b).

With regard to the situation during the last third of intra-uterine development of pigs, evaluation is not possible in the absence of species-specific data on the development of foetal-maternal hormonal relations and feedback mechanism. In stressful situations, mainly of acute character, to which sows are exposed, maternal glucocorticoids can apparently pass through the placenta by passive diffusion as is the case with the other steroids ( $\mathrm{H} \mathbf{i} 1 \mathrm{l}$ and $\mathrm{L} \circ \mathrm{n} \mathrm{g} \circ \mathrm{1980}$ ). However, when exposed to protracted and repeated action of stressors, sows cannot be expected to develop a long-term rise in adrenocortical hormone level ( $\mathrm{A}$ b e $\mathrm{r} / \mathrm{e}$ et al. 1976) in consequence of the adaptation of the organism to environmental conditions. The situation may be complicated by potential differences in the metabolism of foetal and maternai steroids and by the influences of maternal nutrition on hormonal regulation of foetal development and on foetal glucocorticoid receptors ( $M$ u 1 a y et al. 1980). Provided that the feedback mechanisms of foetal pigs are functional, which can reasonably be assumed to be so at the end of their intra-uterine life, then a passively induced rise in their corticosteroid concentration would suppress their own production and this would not result in a permanently increased corticosteroid level unless a prolonged exogenous supply of glucocorticoids was involved. This view is supported by the finding of reduced actual and relative adrenal mass of both newborn and ten-day-old piglets from sows treated with dexamethasone for three days during advanced pregnancy ( $H \ddot{u} h n$ and $K i n p e l$ 1979), since high plasma corticoid level in growing piglets is generally associated with high relative adrenal mass.

\section{Inhibice adrenokortikálni aktivity novorozených selat dexamethazonem}

Dexamethazon $v$ perorální dávce $0,25 \mathrm{mg}$ byl podán polovinè selat dvou vrhú bèhem jedné hodiny po narozenf, polovinè selat dalš́ch dvou vrhú dvakrát 3. den żivota. Za 12 hodin byla všechna vykrvena. U pokusných novorozených selat byla ve srovnánf s kontrolami 
snižena koncèntrace plazmatických 17-hydroxykortikosteroidú (17-OHCS) ०64 8 , u třidenních o $36 \%$. Schopnost produkce 17-OHCS in vitro pri stimulaci s ACTH byla potlačena u prvých $\circ 20 \%$, u druhých o 16 \%. OSetření dexamethazonem ovlivnilo koncentraci kyseliny askorbové $v$ nadledvině, neprûkazně zvýšilo hladinu krevní glukózy a snižilo koncentraci kyseliny askorbové $v$ krevní plazmé $i \mathrm{v}$ játrech, nepúsobilo na hmotnost nadledvin ani nemělo důsledek na počet cirkulujících eosinofilních granulocytů. Prokázaná negativní zpětná vazba se sní̌ením endogenních kortikosteroidú potvrzuje funkění zralost systému hypofýza - nadledviny u novorozených selat. Je diskutováno o feto-maternálních vztazich z hlediska komparativní fyziologie a o mechanismech kontrolujících hladinu kortikosteroidư $v$ perinatálním údobi vývoje selat.

\section{Торможение адренохортихальной ахтижности новорожденных поросят} дехсаметазоном

Дехсаметазов пероральной дозоһ 0,25 мг давали половине поросят двух племенных гнезд в течение одного часа после опороса, половине поросят двух последующих гнезд два раза на 3 сутхи жизни. Все ови были через 12 часов обецхровлены. По сравнению с хонтрольными группами подопыных поросят была понижена хонцентрация плазматических 17-охсихортихостероидов (17-OHCS) на 64 \&, у поросят в возрасте 3 сутох - на 36 8. Способность продухции 17-ОНСS в пробирке при стимуляции с АКтГ была у первых хивотных подавлена на 20 8, у второй группы - на 16 8. Подача дехсаметазона охазала влияние на хонцентрацию асхорбиновов хислоты в надпочечной шелеяе, несущественно увеличилця уровень глюхозы в хрови и повизилаць хонцентрация ахсорбичной хислости в хровянои плазме и печени. Дексаметазов не охазал влияния на массу надпочечных желез и на численность цирхулируопих эоэинофильных гранулоцитов. Установлевия отрицательная обратная связь С понижением эндогенвых хортихостероидов подтверждает фунхииоальнуо эрелость системы гипофиз - надпочечные железы у новорожденных поросят. о́бсуждаетця вопрос плодово-материнских отновевий с точхи зрения сравнительнон физиологии и механизмов, хонтролирующих уровень хортихостерондов в перинатальның пернод развития поросят.

\section{References}

ABERLE, E.D. - RIGGS, B.J. - ALLISTON, C.W. - WILSON, S.P.: Effects of thermal stress, breed and stress susceptibility on corticosterold binding globulin in swine. J. Anim. Sc1., 43, 1976: 816-820.

BLENKINSOPP, E.C. - BLENKINSOPP, W.K.: Effects of glucocort1cold (dexamethasone) on the eosinophils of the rat. J. Endocr., 37, 1967: 463-469.

BRANSONE, E.D.: Regulation of adrenal growth. Differences in the effects of ACTH in noraal and dexamethasone-suppressed guinea pigs. Endocrinology, 83, 1968: 956-964.

BRENNER, K.V. - GURTLER, H.: DIe Konzentration an Kort1801, Glukose und freien Fettsäuren im Blutplasma bel Schweinen In Abhängigkeit von Alter sowle bel Sauen in Zeitraun der Geburt. Arch. exp. Vetked., 31, 1977: 741-747.

CLEVELAND, W.W.: Maternal-fetal hormone relationship. Pediatr. Clinics N. Aner., 17, 1970: 273-289.

COOR, D.B. - GILL, G.V. - JACKSON, I.M.D. - SMART, G.A.: Inhibition by dexamethasone of adrenocorticotrophin and cortisol release induced by intravenous infusion of ATP and dibutyryl cyclic AYP in piglets. J. Endocr., 60, 1974: 65-73.

CORBIER, P. - ROFFI, J.: Increased adrenocortical activity in the newborn rat. Biol. Neonat., 33, 1978: 72-79.

D'ANGELO, S.A. - PAUL, D.H. - WALL, N.R.: Maternal-fetal endocrine Interrelations: influence of maternal adrenocorticosteroids on fetal ACTH secretion. A. J. Physiol., 224, 1973: 543-547.

DOAALD, R.A. - MURPHY, S.S. - MABARRO, J.D.N.: The plasan corticotrophin response to Insulin hypoglycaenia, lysine-vasopressin and wetyrapone in pigs. J. End . 41, 1968: 509-518.

DVOßKX, M.: Hladiny volných 17-hydroxykortikosteroldů v krevní plasně prasat: vztah ke stifi selat. Vet. Ned., Praha, 12, 1967: 43-48.

DVOKRK, M.: Adrenocortical function in foetal, neonatal and young pigs. J. Endocr., 54, 1972: 473-481.

DVOXIK, M.: Development of the adrenal gland In pigs during the perinatal period. Growth rate and ascorbic acid content of the adrenal. Blol. Neonate, 22, 1973a: 338-347. 
DVORK, M.: The relation of starvation to hypoglycaemia and adrenocortical activity in newborn and s1x-week-old p1gleta Zb1. Vet. Med. A, 20, 1973b: 370-381.

DVORKK, M.: Effects of corticotrophin, starvation and glucose on ascorbic acid levels in the blood plasma and liver of piglets. Nutr. Metabol., 16, 1974: 215-222.

FEVRE, J.: Corticostéroids maternels et foetaux chez la truie en $\mathrm{f}$ in de gestation. Compt. rend., Sérte D, 281, 1975: 2009-2012.

GAUNT, R. - CHART, J.J. - RENZI, A.A.: Inhibitors of adrenal cortical function. Rev. Phys1o1. Blochem. exper. Pharmacol., 56, 1965: 113-172.

HART, D.S. - BEAVEN, D.W. - FRANCE, N.C. - ESPINER, E.A.: Lack of ef fect of dexamethasone on the adrenocortical response to corticotrophin in sheep with adrenal autotransplants. J. Endocr., 43, 1969: 191-196.

HILL, E.P. - LONGO, L.D.: Dynamics of maternal-fetal nutrient transfer. Fedn. Proc., 39, 1980: 239-244.

HOHN, R. - KIUPEL, H.: Versuche zur Beelnflussung der Geburt beim Schwein mittels Dexame thason. Arch. exp. Vet. Med., 33, 1979: 247-251.

KAUPPILA, A. - HARTIKAINEN, A.L. - JXRVINEN, P.A. - YLOSTALO, P.: The Influence of complications of pregnancy or delivery upon the maternal and umbilical cord plasma levels of cort1sol. Ann. clin. Res., 4, 1972: 26-29.

KITTINGER, G.W.: Feto-maternal production and transfer of cortisol in the rhesus (Macaca mulatta). Stero1ds, 23, 1974: 229-243.

KLEPAC, R. - MILKOVIC, R.: Fetal rat adrenal growth and steroidogenesis in vitro after maternal dexamethasone treatment. Biol. Neonat., 36, 1979: 154-159.

MULAY, S. - BROWNE, C.A. - VARMA, D.R. - SOLOMON, S.: Placental hormones, nutrition, and fetal development. Fedn Proc., 39, 1980: 261-265.

OKUNO, A. - NISHIMURA, Y. - KAWARAZAKI, T.: Changes in plasma 11-hydroxycort1costero1ds after ACTH, Insulin and dexamethasone in neonatal infants. J. clin. Endocr. Metab., 34, 1972: 516-520.

SCHAPIRO, S.: Neonatal cort1sol administration: Effect on growth, the adrenal gland and p1tultary-adrenal response to stress. Proc. Soc. exp. B1ol. Med., 120, 1.965: 771-774.

SIRETT, N.E. - GIBS, F.P.: Dexamethasone suppression of ACTH release: effect of the Interval between sterold administration and the application of stimuli known to release ACTH. Endocrinology, 85, 1969: 355-359.

TERVILX, L. - TERAMO, K. - RAJAMXKI, A.: Some aspects of the transfer of cortisol from maternal to foetal blood during normal labour. Ann. Ch1r. Gynaecol. Fenn., 58, 1969: 264.

TUCER, S. - JIRMANOVA, I. - ZELENA, J. - HRJER, I. - HNIR, P. - HANZLIKOVA, V. - SYROVP,

I. - BASS, A. - VYSKOCIL, F. - FISCHER, J. - VEJSADA, R.: Roznožka selat z hlediska nervosvalové fyzlologie. Veterináfstvi, 30, 1980: 438-441.

ZELENA, J. - JIRMANOVA, I.: Degenerative changes in skeletal muscles of piglets with congenttal myofibrillar hypoplasia. Zb1. Vet. Med. A, 26, 1979: 652-665. 